\title{
WITCHCRAFT AND WELFARE
}


THIS PAGE INTENTIONALLY LEFT BLANK 


\section{Witchcraft \\ and Welfare}

SPIRITUAL CAPITAL

AND THE BUSINESS OF MAGIC

IN MODERN PUERTO RICO

RAQUEL ROMBERG

$\checkmark$ University of Texas Press, Austin 
Copyright $\left({ }_{2003}\right.$ by the University of Texas Press

All rights reserved

Printed in the United States of America

Second paperback printing, 2004

Requests for permission to reproduce material from this work should be sent to Permissions, University of Texas Press, Box 7819, Austin, TX 78713-7819.

(a) The paper used in this book meets the minimum requirements of ANSI/NISO Z39.48-1992 (RI997)

(Permanence of Paper).

Library of Congress Cataloging-in-Publication Data

Romberg, Raquel.

Witchcraft and welfare : spiritual capital and the business of magic in modern Puerto Rico /

Raquel Romberg.

$$
\text { p. } \quad \mathrm{cm} \text {. }
$$

Includes bibliographical references and index. ISBN 0-292-77123-I (alk. paper) IS в N 0-292-77126-6 (pbk. : alk. paper)

I. Witchcraft-Puerto Rico. 2. Magic-Puerto Rico. I. Title.

BFI584.P9 R66 2003

I33.4'3'097295-dc2I 20020I5I7I 
In dear memory of

Andrés Freiman

Victor Freiman

Haydée Trinidad

Tonio Lacén 
THIS PAGE INTENTIONALLY LEFT BLANK 